\title{
In Vivo Toxicity Study of Nerium oleander's Leaves and Flowers Aqueous Extracts in Mice (Cytogenetic, Biochemical and Hematological Study)
}

\author{
Maha F. Altaee * \\ Received 24, June, 2010 \\ Accepted 26, October, 2010
}

\begin{abstract}
:
The present research was carried out to assess the toxic effect of oral administration of the aqueous extract of Nerium oleander leaves and flowers daily at doses of (25) $\mathrm{mg} / \mathrm{kg}$ body weight for four weeks in mice. The toxicity of this plant parts was determined after two and four weeks by measuring the parameters of cytogenetic (mitotic index, micronucleus \%), and serum levels of the hematological (RBC, Hb, WBC) and biochemical (GOT, GPT, ALT, AST) indexes in comparison with that of the control (normal saline), also clinical signs were determined. The results showed a significant decrease in mitotic index while an obvious raise was seen in micronucleus percentage in comparison with that of the control after the two periods of administration. More over significant marked changes was seen in the level of all the hematological and biochemical parameters when compared with the control. In addition to that, diarrhea with some organ lesions were also observed.
\end{abstract}

Key words: Nerium oleander, cytogenetic, hematology, biochemistry

\section{Introduction:}

Oleander (Nerium oleander) is a drought-tolerant, evergreen flowering shrub that belongs to the Dogbane family, Apocynaceae. It is frequently grown as an ornamental plant in gardens and parks as well as highway median divider or hedge around yards or orchards. Oleander is originally a Mediterranean and Asian plant and is widely distributed in the world, especially in tropical and subtropical regions. The plant is grown throughout Iran and is more common in eastern and southern provinces [1].

Cut or broken branches exude a thick, white sap. The leaves are 5 to 20 $\mathrm{cm}$ long, narrow, acuminated or acute in the apex, shortly petiolate, with a coriaceus dark-green blade. Some cultivars have white or yellow variegated leaves [2]. Flowers are produced in terminal heads and their colors vary from deep pink to white. Each flower is about $5 \mathrm{~cm}$ in diameter with five petals, although some cultivators have double flowers. The fruit consists of a narrow follicle 7.5 to $17.5 \mathrm{~cm}$ long which opens to disperse fluffy seeds. Oleander can be propagated by seed but, being allogamous and highly heterozygous, it shows great variability in seedling populations [3].

Oleander has long been known to be poisonous to animals and human beings. All parts of the plant either fresh or dried are toxic and contain cardiac glycosides, where the roots and seeds having the highest concentrations. The most prominent of those glycosides are oleandrin and neriin [4]. Oleander poisoning is not infrequent in man and domestic

*Biotecchnology Department, College of Science, Baghdad University. 
animals. Cases of accidental toxicosis have been reported in adults and children [5]. The plant has also been used for suicidal or homicidal intent [6]. Accidental and/or experimental oleander toxicosis has been described in cattle [7], horses [8], sheep [1], goats [9], donkeys [10], rats [11] and turkeys [12].

The present study was preformed on mice to evaluate toxic effect of Nerium oleander's aqueous leaf and flower extracts by studying cytogenetic, hematological, biochemical parameters also clinical signs were recorded. Thus, the main aim of this experiment was to evaluate the toxicity of this plant in normal mice.

\section{Materials and Methods:}

All the chemicals were obtained from Sigma Chemical Co. (USA) and BDH (England).

Experimental Animals: Three groups of female albino Swiss BALB/c mice (with five mice in each group) were obtained from the Biotechnology Research Center / AL-Nahrain University, were used in this study. Their ages were ranged between (8-12) weeks and weighting (25-30) gm. They were divided into subgroups, and each group was placed in a separate plastic cage. The cages were kept in a room with (23-25) $\quad \mathrm{C}^{\mathrm{o}}$ temperature. The animals were fed with a suitable quantity of water and complete diet.

\section{Administration of Experimental} Animals: The animals in this experiment were treated with a cumulative dose of oleander leaves and flowers for four weeks. The mice were divided into five experimental groups, each group consisted of (5) mice and to which the oleander was administered orally.

Group 1: negative control (5mice), treated with $(0.1 \mathrm{ml})$ of normal phosphate buffer saline (pH:7.2, 8.5 gm/l)

Group 2: oleander leaf treatment (5mice), treated with $(0.1 \mathrm{ml})$ of $(25 \mathrm{mg} / \mathrm{Kg})$ for two weeks.

Group 3: oleander leaf treatment (5mice), treated with $(0.1 \mathrm{ml})$ of $(25 \mathrm{mg} / \mathrm{Kg})$ for four weeks.

Group 4: oleander flower treatment (5mice), treated with $(0.1 \mathrm{ml})$ of $(25 \mathrm{mg} / \mathrm{Kg})$ for two weeks.

Group 5: oleander flower treatment (5mice), treated with $(0.1 \mathrm{ml})$ of $(25 \mathrm{mg} / \mathrm{Kg})$ for four weeks.

The animals were monitored for apparent signs of toxicity. Then they were sacrificed on the $15^{\text {th }}$ and $29^{\text {th }}$ day after administration and the blood was separated to measure the levels of biochemical and hematological parameters, also the clinical and pathological signs were recorded. More over, the bone marrow was collected to determine the mitotic index and $\mathrm{MN}$ percentage for cytogenetic study.

Preparation of the flowers and leaves aqueous extract: Fresh plant material was washed by distilled water. A $500 \mathrm{~g}$ quantity of plant material was cut into small pieces and grind in a warring blender with $500 \mathrm{ml}$ of phosphate buffer saline and then the aqueous extracts were boiled over low 
flame for (15)minutes. The flask was then plugged and removed from the heat and allowed to cool. After cooling the content of the flask was filtered and dried to prepare the required dose $(25 \mathrm{mg} / \mathrm{Kg})$ [13].

\section{Chromosomal preparation from} somatic cells of the mouse bone marrow: This experiment was done according to [14]. Each animal was injected with $0.25 \mathrm{ml}$ of colchicine with a concentration of $(1 \mathrm{mg} / \mathrm{ml})$ intraperitoneally (I.P) $2 \mathrm{hr}$ before sacrificing the animal, Then the animal was sacrificed by cervical dislocation and fixed on its ventral side on the anatomy plate and the abdominal side of the animal and its thigh region were swabbed with $70 \%$ ethanol. The femur bone was then taken and cleaned from the other tissues and muscles and gabbed from the middle with a forceps in a vertical position over the edge of the test tube, and by sterile syringe $5 \mathrm{ml}$ of PBS were injected so as to wash and drop the bone marrow in the test tube. The test tube was taken and centrifuged at speed of $2000 \mathrm{rpm}$ for $10 \mathrm{~min}$. After that the supernatant was removed and $5 \mathrm{ml}$ of potassium chloride (0.075) $\mathrm{M}$ was added as a hypotonic solution, then the test tubes were left for $30 \mathrm{~min}$ in the water bath at $37 \mathrm{C}^{\circ}$ and shaked from time to time. The tubes were then centrifuged at $2000 \mathrm{rpm}$ for $10 \mathrm{~min}$ and the supernatant was removed and the fixative solution was added (as drops) on the inside wall of the test tube with the continuous shaking, the volume was fixed to $5 \mathrm{ml}$ and the content shaked well. The tube was kept at $4 \mathrm{C}^{\circ}$ for 30min to fix the cells. After that the tubes were centrifuged at $2000 \mathrm{rpm}$ for $10 \mathrm{~min}$. The process was repeated three times and the cells were suspended in $2 \mathrm{ml}$ of the fixative solution. By a pasture pipette, few drops from the tube were dropped vertically on the chilled slides from a height of 3 feet at a rate of (4-5) drops to give the chance for the chromosomes to spread well. Later the slides were kept to dry at room temperature, and then stained with Giemsa stain and left for $15 \mathrm{~min}$ and washed with D.W. .

Micronucleus test in mouse bone marrow cells: This assay was adapted from that described by [14]. The femur bone was cleaned from tissue and muscles, then gapped from the middle with a forceps in a vertical position over the edge of a test tube, and by a sterile syringe $1 \mathrm{ml}$ of human serum was injected so as to wash and drop the bone marrow in the test tube. Then the test tube was centrifuged at $1000 \mathrm{rpm}$ for $5 \mathrm{~min}$. Later the supernatant was removed, and a drop from the pellet was taken to make a smear on clean slides and the slides were kept at room temperature for $24 \mathrm{hr}$. Finally the slides were fixed with absolute methanol for 5 min, then stained with Giemsa stain for $15 \mathrm{~min}$ and washed with D.W. and left to dry. Two slides for each animal were prepared for micronucleus test.

Blood collection: Blood was collected from the heart of the mice and divided into two parts, one for hematological examination with EDTA, and the other for biochemical examination after the separation of serum.

\section{Hematological and biochemical examination: This study established the hematological changes such as (heamoglobin concentration $(\mathrm{Hb})$, red blood cell count (RBC) and white blood cell count (WBC) [15], and biochemical changes which include serum enzymes activity (aspartate and alanine aminotranferase activities (AST and ALT) and (glutamic oxalocetic transaminase (GOT) and glutamic pyruvic transaminase (GPT))}


by using commercial kits (Biomerex, France) [16].

Statistical Analysis: Data were analyzed by 1-way analysis of variance with ANOVA- test. Data are presented as means \pm SE. The level of significance was $P<0.05$. [17].

\section{Results and Discussion:}

After the oral administration of the Nerium oleander extracts for both the leaves and flowers for the mice at dose of $(25 \mathrm{mg} / \mathrm{kg})$, the mice were sacrificed after two and four weeks and the toxicity of the oleander was measured. First detection involves the determination of both mitotic index and MN\% for cytogenetic examination. The results show that after both the two and four weeks, this plant cause significant decrease in mitotic activity in comparison with control (55.40) which became near to (23.00) after four week exposure to flower aqueous extract. While significant increase in the percentage of $\mathrm{MN} \%$ which reached to (9.34) was also observed after treatment with the flower extract when compared with the control (2.25) as shown in table (1), and thus the flower cause more toxicity than leaves. Toxicity of Nerium oleander leaves and flowers has been detected and measured in human and different animals at different levels [3, 18].

Oleander (Nerium oleander) poisoning is a common problem found in many parts of the world. The oleander toxicity is due to oleandrin (the principle cardiac glycoside of oleander) and its aglycone metabolites oleandrigenin which were found in both leaves and flowers [19]. The cytotoxic or antimitotic action of oleander has also been detected by other researchers [20], in which they studied both the antimitotic and the antispermatogenic effect of this plant. They also proved that oleander has significant level of toxicity.

Table (1): Cytogenetic effect of oral administration of $N$. oleander on mice for 2 and 4 weeks in comparison with control.

\begin{tabular}{|c|c|c|}
\hline Groups & $\begin{array}{l}\text { Mitotic } \\
\text { Index } \\
\text { mean } \pm S E\end{array}$ & $\begin{array}{l}\text { Micronucleus\% } \\
\text { mean } \pm \text { SE }\end{array}$ \\
\hline $\begin{array}{l}\begin{array}{l}\text { Control } \\
\text { (saline) }\end{array} \\
\end{array}$ & $55.40 \pm 0.13$ & $2.25 \pm 0.11$ \\
\hline $\begin{array}{l}\text { N. oleander } \\
\text { leaf ( } 2 \text { weeks) }\end{array}$ & $35.10 * \pm 0.26$ & $3.50 * \pm 0.30$ \\
\hline $\begin{array}{l}\text { N. oleander } \\
\text { leaf (4 weeks) }\end{array}$ & $26.06^{*} \pm 0.63$ & $6.80 * \pm 0.05$ \\
\hline $\begin{array}{l}\text { N. oleander } \\
\text { flower } \\
\text { weeks })\end{array}$ & $31.33^{*} \pm 0.45$ & $5.66 * \pm 0.51$ \\
\hline $\begin{array}{l}\text { N. oleander } \\
\text { flower } \\
\text { weeks })\end{array}$ & $23.00 * \pm 0.89$ & $9.34 * \pm 0.09$ \\
\hline
\end{tabular}

*Significant different from control values. $\mathbf{P}<0.05$

More over,this study involved the determination of both hematological and biochemical changes in mice. Results revealed that both $N$. oleander leaves and flowers made significant changes in the all parameters of hematology including determination of (WBCs, RBCs and $\mathrm{Hb}$ ). However significant changes were seen in these all parameters and after two and four weeks when compared with controls as shown in table (2).

Table(2):Hematological examination of mice after oral administration of $N$. oleander for 2 and 4 weeks in comparison with control. (Mean \pm SE)

\begin{tabular}{|c|c|c|c|}
\hline Groups & $\begin{array}{c}\text { WBCs } \\
\mathbf{1 0}^{\mathbf{3}} / \mathbf{m m}^{\mathbf{3}}\end{array}$ & $\begin{array}{c}\mathbf{R B C s} \\
\mathbf{1 0}^{\mathbf{6}} / \mathbf{m m}^{\mathbf{3}}\end{array}$ & $\begin{array}{c}\mathbf{H b} \\
\mathbf{g} / \mathbf{d l}\end{array}$ \\
\hline $\begin{array}{c}\text { Control } \\
\text { (saline) }\end{array}$ & $3.100 \pm 0.27$ & $4.58 \pm 0.45$ & $14.6 \pm 0.71$ \\
\hline $\begin{array}{c}\text { N. oleander } \\
\text { leaf }(\mathbf{2} \\
\text { weeks) }\end{array}$ & $6.400 * \pm 0.35$ & $2.42 * \pm 0.24$ & $12.2 * \pm 0.64$ \\
\hline $\begin{array}{c}\text { N. oleander } \\
\text { leaf } \mathbf{( 4} \\
\text { weeks) }\end{array}$ & $8.210 * \pm 0.47$ & $1.22 * \pm 0.38$ & $10.4 * \pm 0.90$ \\
\hline $\begin{array}{c}\text { N. oleander } \\
\text { flower }(\mathbf{2} \\
\text { weeks) }\end{array}$ & $5.376 * \pm 0.88$ & $2.78 * \pm 0.18$ & $11.7 * \pm 0.92$ \\
\hline N. oleander & $8.514 * \pm 0.34$ & $0.98 * \pm 0.27$ & $10.1 * \pm 0.38$ \\
\hline
\end{tabular}




\section{\begin{tabular}{|c|l|l|l|}
\hline $\begin{array}{c}\text { flower (4 } \\
\text { weeks) }\end{array}$ & & & \\
\hline
\end{tabular} \\ *Significant different from control values. $\mathbf{P}<0.05$}

Similar results were also obtained by many authors, in which they studied also the hematological changes that occur after treatment with $N$. oleander and in different animals as including rabbit [13], rat [11] and mice [20]. Also this plant cause obvious changes in biochemical parameters when compared with control. Significant changes were seen in the level of all the studied enzymes when compared with the saline treated mice and at the both periods of oral administration of oleander as shown in table (3).

Table (3): Biochemical examination of mice after Oral Administration of $N$. oleander for 2 and 4 weeks in comparison with control. (Mean \pm SE)

\begin{tabular}{|c|c|c|c|c|}
\hline Groups & $\begin{array}{c}\text { ALT } \\
\text { IU/L }\end{array}$ & $\begin{array}{c}\text { AST } \\
\text { IU/L }\end{array}$ & $\begin{array}{c}\text { GOT } \\
\text { IU/L }\end{array}$ & $\begin{array}{c}\text { GPT } \\
\text { IU/L }\end{array}$ \\
\hline $\begin{array}{c}\text { Control } \\
\text { (saline) }\end{array}$ & $21 \pm 5.22$ & $40 \pm 3.20$ & $145 \pm 2.10$ & $57.01 \pm 2.33$ \\
\hline $\begin{array}{c}\text { N. oleander } \\
\text { leaf (2 weeks) }\end{array}$ & $42^{*} \pm 3.45$ & $65^{*} \pm 0.92$ & $169^{*} \pm 2.15$ & $86.43^{*} \pm 3.51$ \\
\hline $\begin{array}{c}\text { N. oleander } \\
\text { leaf (4 weeks) }\end{array}$ & $73^{*} \pm 1.50$ & $92^{*} \pm 6.04$ & $185^{*} \pm 3.35$ & $101.20^{*} \pm 5.08$ \\
\hline $\begin{array}{c}\text { N. oleander } \\
\text { flower (2weeks) }\end{array}$ & $55^{*} \pm 2.83$ & $69^{*} \pm 3.12$ & $167^{*} \pm 1.60$ & $77.65^{*} \pm 2.89$ \\
\hline $\begin{array}{c}\text { N. oleander } \\
\text { flower (4 weeks) }\end{array}$ & $71^{*} \pm 1.90$ & $88^{*} \pm 3.39$ & $191^{*} \pm 1.88$ & $96.73^{*} \pm 1.55$ \\
\hline
\end{tabular}

*Significant different from control values. $\mathbf{P}<0.05$

Biochemical changes that made after oleander treatment had been recorded also by many researchers and also in different animals, as seen in rabbits [13], rat [11] and in human [5]. These abnormal changes that seen in both hematological and biochemical parameters were due to the damage that occur in most organs of the mice, including heart, kidney lung, spleen and liver. In fact lesions were noticed in these all organs after the killing of the mice, liver and spleen enlargement were also observed. Diarrhea was also recorded in the treated animals when compared with untreated ones. However, although histopathological study was not determined in this work but it has been made by some local and national researchers in which they mention that oleander cause significant tissue destruction in many organs [4] in goat and in rat [11]. However, organ destruction is due to the toxic content of oleander glycoside which was shown to act directly on the heart, causing cardiac arrhythmias and heart block [21], and on gastrointestinal tract causing enteritis, abdominal pain and diarrhea [22, 23].

\section{References:}

1. Aslani, MR 2004. Poisonous plants of Iran andtheir effects on animals. 1st. Edn., Mashhad, Mashhad University Press. PP: 210-212.

2. Bai L. 2007. Bioactive pregnanes from Nerium oleander. J. Natur. Prod., 70(1):14-8.

3. Vikas, G. and Payal M. 2010. Phytochemical and pharmacological potential of Nerium oleander. Iinter. J. Pharma. Scien. Res., 1(3): 21-27.

4. Aslani, M. R.1; Movassaghi, A. R.; Janati-Pirouz, H. and Karazma, M. 2007. Experimental oleander (Nerium oleander) poisoning in goats: a clinical and pathological study. Iranian J. Veterin. Resear., 8(1): 58-63.

5. Ege, A.; Berivan, B. and Kadri, A. 2009. Probable hepatotoxicity related to Nerium oleander extract. J. Altern. Complmen. Med., 15(12): 1271-1279.

6. Lim, DC; Hegewald, K; Dandamudi, N and Pettis, LJ 1999. A suicide attempt with an oleander cocktail. Chest., 116: 405-406.

7. Aslani, MR and Rezakhani, A 2000. A case report of oleander (Nerium oleander) intoxication in cattle. Int. J. Trop. Agric., 18:185187. 
8. Hughes, KJ; Dart, AJ and Hodgson, DR 2002. Suspected Nerium oleander (Oleander) poisoning in a horse. Aust. Vet. J., 80: 412-416.

9. Barbosa, R. R.; Fontenele, J. D. and Soto-Blanco B. 2008. Toxicity in goats caused by oleander (Nerium oleander). Res. Veter. Scie., 85(2): 279-281.

10. Smith, PA; Adridge, BM and Kittleson, MD 2003. Oleander toxicosis in a donkey. J.Vet. Intern. Med., 17: 111-114.

11. Yahaya, M. A.; AL-Farhan A. H. and Adam S. E. 2000. Preliminary toxicity study on the individual and combined effects of Citrullus colocynthis and Nerium oleander in rats. Fitoterapia, 71(4): 385-391.

12. Shlosberg, A; Ohad, DG; Bellaiche, M and Perl, S 2004. Monitoring of physiological and pathological changes in turkey poults fed leaves of potentially cardiomyotoxic Nerium oleander and Persea ameicana. In: Acamovic, T; Stewart, CS and Pennycott, TW (Eds.), Poisonous plants and related toxins. (1st. Edn.), Massachusetts, CABI Publishing. PP: 131-136.

13. Al-Farwachi, M. I.; Rahymah, M. S. and Al-Badrani, B. A. 2008. Acute toxicity of Nerium oleander aqueous leaf extract in rabbits. Iraqi J. Veterin. Scien., 22(1): 1-4.

14. Allen, J. W.; Shuler, C. F.; Memnders, R. W. and Olatt, S. A. 1976. A simplified technique for in vivo analysis of sister chromatid exchange using 5bromodeoxyuridine tablets. Cytogen. Cell Genet., 18: 231-237.

15. Coles, E. H. 1986. Veterinary Clinical Pathology. W. B. Saunders Company, London. Pp:17-35.
16. Robyt, J. F. and White, B. J. 1987. Biochemical Techniques Theeory and Practice. Jowa state University Brooke Cole Publishing Company, Monterey California. Pp: 74-87.

17. Al-Mohammed N. T.; Al-Rawi K. M.; Younis M. A. and Al-Morani W. K. 1986. Principle of Statistics. J. Al-Mousl University (in Arabic).

18. Langford, S. D. and Boor, P. J. 1996. Oleander toxicity: an examination of human and animal toxic exposures. Toxicology, 109(1): 1-13.

19. Asheesh K. T; Robert H. P. and Birgit P. 2009. In vitro study of the effectiveness of three commercial adsorbents for binding oleander toxins. Clinic. Toxico., 47(3): 213218.

20. Narayane, V. S.; Pawakar, A. P.; Souza, A. A. and Karande, H. A. 2009. Toxicity studies on Nerium oleander leaf extract in male albino mice: an approach to develop oral contraceptive. J. Herb. Med. Toxicol., 3(1): 95-104.

21. Siemens, L. M.; Galey, F. D. and Johnson, B. 1995. The clinical, cardiac and pathophysiological effect of oleander toxicity in horse.J. Vet. Inter. Med., 9:217222.

22. Oryan, A.; Maham, A. and Rezakani, M. 1996. Morphological studies on experimental oleander poisoning in cattle.Zentral. Vet. Med., 43:625-634.

23. Radostitis, O. M.; Gay, C. C.; Blood, D. C. and Hinch, K. W. 2000. Veterinary Medicine: textbook of disease of cattle, sheep, pig and horse. $9^{\text {th }}$ edition, Philadelphia, WB Sanders Company. 


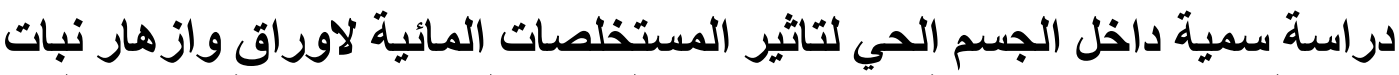
الدفلة في الفئران (دراسة العوامل الوراثية الخلوية والكيموحيوية والدموية لألماتية مها فنري مجبي"* |قسم التقانة الاحبائية , كلية العلوم , جامعة بغداد.

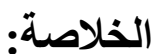

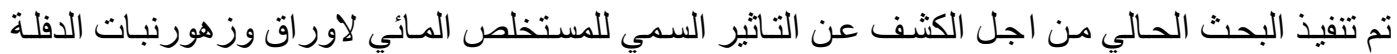

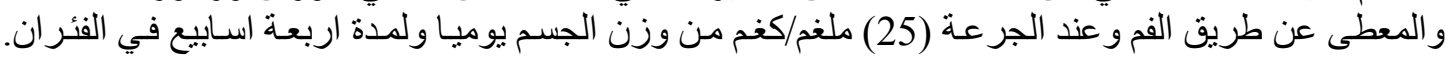

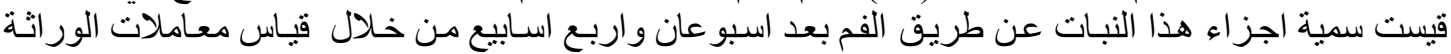
الخلوية (معدل الانقسام الخيطي و النو اة الصغيرة) ومعدل التغير ات الدموية (RBC, Hb, WBC) و المؤشر اتشرات

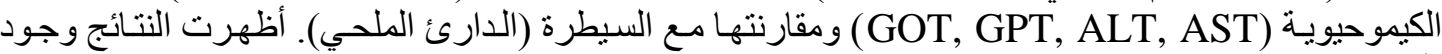

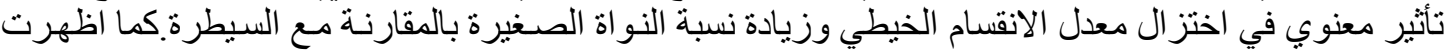

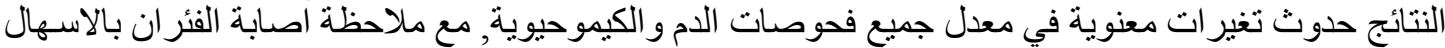
وحدوث افات موضعية في بعض الاعضئ فئاء. 